Instituto Internacional de Investigación y Desarrollo Tecnológico Educativo INDTEC, C.A.

DOI: https://doi.org/10.29394/Scientific.issn.2542-2987.2020.5.17.0.10-17

OAI-PMH: http://www.indteca.com/ojs/index.php/Revista Scientific/oai

\title{
Claves para el desarrollo de la docencia en la Educación Superior en condiciones de aislamiento y distanciamiento
}

PhD. Belinda Marta Lema Cachinell Instituto Superior Tecnológico de Formación Profesional Administrativa y Comercial, ITF martalema@formacion.edu.ec Guayaquil, Ecuador https://orcid.org/0000-0002-1403-336X

\section{Editorial}

La publicación del presente número de esta prestigiosa revista en la actual coyuntura de desarrollo de la humanidad, sacudida por la pandemia del COVID-19, brinda la posibilidad de rendir sentido tributo, desde estas páginas comprometidas con el quehacer educativo e investigativo, a todos los seres humanos que, en primera persona, experimentaron y lo continúan haciendo, las devastadoras consecuencias de un virus cuyo impacto todavía no se alcanza a valorar en toda su magnitud.

En ese contexto, una mención especial la merecen quienes, con su silencio y descanso eterno, nos continúan alertando acerca del peligro de una situación que está lejos de ser controlada y que sigue convocando a la entrega $y$ al servicio sanitario comprometido a un humano ejército de profesionales de la salud y de otras áreas que se mantienen ocupando las primeras líneas en el enfrentamiento de la pandemia en todo el mundo.

La situación generada por el COVID-19 puso también a prueba la capacidad de respuesta de las Instituciones de Educación Superior (IES) para seguir garantizando la formación de profesionales en las nuevas condiciones en las que, primero el aislamiento y luego el distanciamiento, hicieron imposible su realización de manera presencial.

Ante esta realidad, como se refleja en algunos de los artículos incluidos en este número, las IES concentraron su mirada en las posibilidades educativas de las Tecnologías de la Información y de la Comunicación, llamadas a convertirse en un aliado indispensable para asumir los desafíos 
impuestos por una situación nunca antes experimentada por las generaciones que hoy están representadas en las aulas universitarias.

Desde esa perspectiva, se catalizó la transformación de la educación, como señalan Loveless y Wiliamson (2017):

En un dominio cada vez más híbrido en el que se ensamblan artefactos tecnológicos, acción humana físicamente encarnada, relaciones e instituciones sociales y una variada gama de nuevas y emergentes teorías y prácticas que atañen al aprendizaje, al currículo y a la pedagogía (pág. 14).

En esa línea de pensamiento se hace necesario considerar que una de las claves de la referida transformación consiste en la comprensión de la que la misma no es exclusivamente una cuestión tecnológica, orientada al acceso, a disponer de nuevos canales para la comunicación y el intercambio de información, dirigidos a promover nuevos aprendizajes.

Evidentemente, el desafío es mucho mayor pues implica el despliegue de todas las competencias tecnológicas, pedagógicas, didácticas, metodológicas y emocionales del profesorado para asumir la orientación y el acompañamiento de un masivo e inédito proceso de enseñanza aprendizaje en el que, de un modo vertiginoso y no previsto, se vieron inmersos casi de manera repentina, docentes y estudiantes.

A propósito, vale la pena subrayar que, como indican Castañeda y Selwyn (2019): en ese encomiable esfuerzo resulta indispensable mantener el aprendizaje y la formación integral de los futuros profesionales en el centro de atención, promoviendo la renovación de la Educación Superior que implica la repotenciación de su capacidad para el cumplimiento de su responsabilidad social.

Para Souto, Torres-Coronas y Arias-Oliva (2015): el logro de tan alto propósito, mucho más en el marco de la pandemia del COVID-19, resulta imprescindible que las IES asuman con mayor intensidad y efectividad el 
trabajo dirigido al máximo desarrollo de las competencias socioemocionales de docentes y estudiantes, con la finalidad de favorecer su formación académica, profesional y sus capacidades personales y sociales.

No hay que obviar que, en medio de una situación de tanta complejidad, la mediación del docente, sus competencias para una comunicación asertiva, el establecimiento de un clima emocional positivo, el apoyo entre compañeros y el respeto de las reglas para el comportamiento en los entornos virtuales de aprendizaje se convierten en aspectos claves para el desarrollo de la docencia en la Educación Superior en un escenario que meses atrás era prácticamente imposible de imaginar.

En consonancia con ello, cabe resaltar el significado de la labor del profesorado de las IES, que a nivel personal experimenta las tensiones y el estrés generado por los distintos factores asociados al COVID-19, incluida la pérdida de seres queridos, en ocasiones de alguno de sus estudiantes, pero se mantienen aferrados a la docencia, a su genuina vocación de servicio que es, al mismo tiempo, garante de la continuidad de la formación de los profesionales que el país necesita.

Con ese espíritu, la Educación Superior continuará aportando, desde la investigación científica y su invariable compromiso con la prevención, al esfuerzo de toda la sociedad para la superación de la crisis del coronavirus, de la que también será capaz de extraer las lecciones que le permitan su legítima reconfiguración para responder a los crecientes retos del mundo, de cuya constante transformación no hemos de ser únicamente testigos presenciales sino decididos protagonistas activos.

Palabras clave: desarrollo de la educación; docencia; editorial.

Fecha de Recepción: 10-04-2020
Fecha de Aceptación: 02-06-2020
Fecha de Publicación: 05-08-2020 


\section{Keys to the development of teaching in Higher Education in conditions of isolation and distance}

\section{Editorial}

The publication of this issue of this prestigious magazine in the current conjuncture of development of humanity, shaken by the COVID-19 pandemic, offers the possibility of paying tribute, from these pages committed to the educational and investigative work, to all human beings who, in the first person, experienced and continue to do so, the devastating consequences of a virus whose impact has not yet been fully appreciated.

In this context, a special mention is deserved by those who, with their silence and eternal rest, continue to alert us about the danger of a situation that is far from being controlled and that continues to call for the delivery and committed health service to a human army of health and other professionals who remain at the forefront of the pandemic worldwide.

The situation generated by COVID-19 also tested the response capacity of Higher Education Institutions (IES) to continue guaranteeing the training of professionals in the new conditions in which, first isolation and then distancing, made it impossible its realization in person.

Faced with this reality, as reflected in some of the articles included in this issue, IES focused their attention on the educational possibilities of Information and Communication Technologies, called to become an indispensable ally to meet the challenges imposed by a situation never before experienced by the generations that today are represented in university classrooms.

From this perspective, the transformation of education was catalyzed, as Loveless and Wiliamson (2017) point out: "in an increasingly hybrid domain in which technological artifacts, physically incarnated human action, social institutions and relationships, and a wide range of new and emerging theories and practices that concern learning, curriculum and pedagogy are assembled" 
(p. 14).

In this line of thought, it is necessary to consider that one of the keys to the aforementioned transformation consists in understanding that it is not exclusively a technological issue, oriented to access, to having new channels for communication and the exchange of information. information, aimed at promoting new learning.

Obviously, the challenge is much greater since it involves the deployment of all the technological, pedagogical, didactic, methodological and emotional competences of teachers to assume the orientation and accompaniment of a massive and unprecedented teaching-learning process in which, in a dizzying way and unforeseen, teachers and students were immersed almost suddenly.

By the way, it is worth underlining that, as Castañeda and Selwyn (2019) indicate: in this commendable effort it is essential to maintain the learning and comprehensive training of future professionals in the spotlight, promoting the renewal of Higher Education that implies the repowering of its capacity to fulfill its social responsibility.

For Souto, Torres-Coronas and Arias-Oliva (2015): the achievement of such a high purpose, much more in the context of the COVID-19 pandemic, it is essential that IES undertake the work directed to the maximum with greater intensity and effectiveness development of the social-emotional competences of teachers and students, in order to promote their academic, professional training and their personal and social capacities.

It should not be forgotten that, in the midst of such a complex situation, the mediation of the teacher, his competencies for assertive communication, the establishment of a positive emotional climate, support among peers and respect for the rules for behavior in Virtual learning environments become key aspects for the development of teaching in Higher Education in a setting that months before was practically impossible to imagine. 
In line with this, it is worth highlighting the meaning of the work of IES teachers, who personally experience the tensions and stress generated by the different factors associated with COVID-19, including the loss of loved ones, sometimes some of its students, but they remain attached to teaching, to their genuine vocation of service, which is, at the same time, guarantor of the continuity of professional training that the country needs.

In this spirit, Higher Education will continue to contribute, from scientific research and its unwavering commitment to prevention, to the effort of the entire society to overcome the coronavirus crisis, from which it will also be able to extract the lessons that allow it its legitimate reconfiguration to respond to the growing challenges of the world, of whose constant transformation we must not only be eyewitnesses but determined active protagonists.

Keywords: educational development; teaching profession; publisher.

Date Received: 10-04-2020
Date Acceptance:

02-06-2020
Date Publication:

05-08-2020 


\section{Referencias}

Castañeda, L., \& Selwyn, N. (Ed.). (2019). Reiniciando la universidad: Buscando un modelo de Universidad en tiempos digitales. ISBN: 978-84-918-0522-9. Barcelona, España, Editorial UOC Universitat Oberta de Catalunya.

Loveless, A., \& Williamson, B. (2017). Nuevas identidades de aprendizaje en la era digital: Creatividad, educación, tecnología, sociedad. ISBN: 978-84-277-2341-2. Madrid, España: Narcea, S.A. de Ediciones.

Souto, M., Torres-Coronas, T., \& Arias-Oliva, M. (2015). Barreras para la inclusión de las competencias emocionales en la educación superior. Opción, 31(5), 1140-1158, e-ISSN: 1012-1587. Recuperado de: https://www.redalyc.org/pdf/310/31045570063.pdf 
PhD. Belinda Marta Lema Cachinell

e-mail: martalema@formacion.edu.ec

Nacida en Guayaquil, Ecuador 29 de diciembre del 1972.

Rectora del Instituto Superior Tecnológico de Formación

Profesional Administrativa y Comercial (ITF); Ingeniera Comercial graduada de la Universidad de Guayaquil (UG), poseo un Diplomado Superior en Currículo por Competencias de la Universidad Técnica de Ambato (UTA); Magister en Gerencia Educativa de la Universidad Metropolitana (UMET); y Doctora en Ciencias de la Gestión por la Caribbean International University (CIU) de Curazao; Doctora en Ciencia Pedagógicas por la Universidad de Oriente (UO) de Santiago de Cuba; acreditada para realizar actividades de investigación en el Ecuador con el No. REG-INV-15-00912 Registro Nacional de Investigadores, avalado por la Secretaría de Educación Superior, Ciencia, Tecnología e Innovación (SENESCYT); miembro de la red de investigación internacional RED-DEES; evaluadora externa de la Revista de Investigación, Formación y Desarrollo: Generando Productividad Institucional (ISSN: 13909681; e- ISSN: 1390-9789) ubicada en catálogo LATINDEX. 